\title{
Blending Proteins in High Moisture Extrusion to Design Meat Analogues: Rheological Properties, Morphology Development and Product Properties
}

\author{
Patrick Wittek (D), Heike P. Karbstein (1) and M. Azad Emin *
}

check for

updates

Citation: Wittek, P.; Karbstein, H.P.; Emin, M.A. Blending Proteins in High Moisture Extrusion to Design Meat Analogues: Rheological Properties, Morphology Development and Product Properties. Foods 2021, 10, 1509. https://doi.org/10.3390/foods 10071509

Academic Editor:

María José Beriáin Apesteguía

Received: 3 June 2021

Accepted: 24 June 2021

Published: 30 June 2021

Publisher's Note: MDPI stays neutral with regard to jurisdictional claims in published maps and institutional affiliations.

Copyright: (c) 2021 by the authors. Licensee MDPI, Basel, Switzerland. This article is an open access article distributed under the terms and conditions of the Creative Commons Attribution (CC BY) license (https:/ / creativecommons.org/licenses/by/ $4.0 /)$.
Institute of Process Engineering in Life Sciences, Food Process Engineering, Karlsruhe Institute of Technology, 76131 Karlsruhe, Germany; patrick.wittek@kit.edu (P.W.); heike.karbstein@kit.edu (H.P.K.)

* Correspondence: azad.emin@kit.edu; Tel.: +49-(0)721-608-48311

\begin{abstract}
High moisture extrusion (HME) of meat analogues is often performed with raw materials containing multiple components, e.g., blends of different protein-rich raw materials. For instance, blends of soy protein isolate (SPI) and another component, such as wheat gluten, are used particularly frequently. The positive effect of blending on product texture is well known but not yet well understood. Therefore, this work targets investigating the influence of blending in HME at a mechanistic level. For this, SPI and a model protein, whey protein concentrate (WPC), were blended at three different ratios (100:0, 85:15, 70:30) and extruded at typical HME conditions (55\% water content, $115 / 125 / 133{ }^{\circ} \mathrm{C}$ material temperature). Process conditions, rheological properties, morphology development, product structure and product texture were analysed. With increasing WPC percentage, the anisotropic structures became more pronounced and the anisotropy index $(A I)$ higher. The achieved $A I$ from the extrudates with a ratio of 70:30 (SPI:WPC) were considerably higher than comparable extrudates reported in other studies. In all extrudates, a multiphase system was visible whose morphology had changed due to the WPC addition. The WPC led to the formation of a much smaller dispersed phase compared to the overlying multiphase structure, the size of which depends on the thermomechanical stresses. These findings demonstrate that targeted mixing of protein-rich raw materials could be a promising method to tailor the texture of extruded meat analogues.
\end{abstract}

Keywords: high moisture extrusion; meat analogue; soy protein; whey protein; protein blends; rheological properties; morphology development; texturisation

\section{Introduction}

High moisture extrusion (HME) can be used to produce meat analogues from plantbased, protein-rich raw materials that are intended to mimic meat in terms of its unique structure, texture, and mouthfeel [1,2]. The studies on HME, which started in the 1980s [3-5], can basically be classified into two different categories, which refer to the use of the raw material, either single-component, where only a single protein-rich raw material (e.g., a protein concentrate or isolate) was used [3,6-12], or multi-component, where two or more raw materials were mixed together [13-21]. For both categories, it was shown that anisotropic meat-like structures were created in the process. Nevertheless, the multi-component systems tended to have a more meat-like product structure and texture compared to the single-component systems [1,18]. Different factors were suggested to be the cause of this effect, such as the formation of a dispersed phase from the added component $[1,22,23]$, the influence of the component on protein aggregation/crosslinking reactions [17,18], or changes of the rheological properties [19]. However, there is still a lack of understanding of what the positive effect of adding a second protein-rich raw material in HME on the product structure is based on.

In our previous work, we showed that a multiphase system is formed in the singlecomponent extrudates based on soy protein isolate (SPI) in which the phases differ in their 
water concentration [10]. According to the model of Tolstoguzov [24], this multiphase system arises as a result of the thermodynamic incompatibility of the proteins involved. The compatibility between proteins is determined by their differences in hydrophilicity, the ratio of molecular weights, and their conformational state $[25,26]$. This phase separation can also occur in a single component system such as SPI [10], which for instance naturally involves more than two protein fractions (e.g., B-conglycinin and glycinin) [27] with different hydrophilicity. These differences in hydrophilicity lead to the apparent phasedependent water concentration, where the phase with the more hydrophilic proteins has a higher water concentration [26].

Due to the thermomechanical stresses in the extrusion process, the morphology of the multiphase system is subjected to changes, as, it can deform, break up and/or coalesce [28]. The rheological properties therefore play a major role, which in turn depend on the composition of the proteins respectively the raw material [29]. For example, Dekkers et al. [30] were able to show in a highly concentrated system that the addition of wheat gluten led to a reduction in the storage modulus $\mathrm{G}^{\prime}$ of SPI.

If these findings on phase separation and phase behaviour in highly concentrated protein systems are taken as a basis, it can be expected that the admixture of another protein-rich raw material will affect the morphology, water distribution and rheological properties of the system and therefore lead to a change in the product structure and texture.

In order to better understand these interrelationships, we blended two protein-rich raw materials in this study. The main raw material is soy protein isolate, which is known to form anisotropic structures as a single component in HME [10,12,31]. Whey protein concentrate (WPC) is used as the protein-rich model raw material to be added to the SPI and is admixed in two concentrations (15 and 30\%) to obtain three mixing ratios: 100:0, 85:15 and 70:30. Whey proteins were chosen as a model protein because, compared to soy proteins, they possess a distinctively different amino acid composition [32], which should enhance the differences in hydrophilicity and therefore the effect on the system. Additionally, a mixture of plant and animal proteins could prove advantageous for the product properties. Blending can increase nutritive value by complementing amino acid profiles [33,34], as plant-based proteins often have fewer indispensable amino acids and therefore lower PDCAAS-scores $[35,36]$. It can also improve sensory and textural properties, as proteins from animal origin generally have less off-flavor [37] and specifically, whey proteins were shown to improve creaminess and mouthfeel by acting as a fat replacer [38].

The influence of the added whey proteins on the rheological properties of the blends was investigated under extrusion-like conditions. The blends were extruded at different temperatures and the influence of the whey proteins on the process conditions, the anisotropic product structure, the extrudates morphology development respectively water distribution and the textural properties were determined. In addition, the phase behaviour and morphology of the whey proteins in the overall matrix were investigated.

\section{Material and Methods}

\subsection{Material}

Commercial soy protein isolate Supro ST from Solae LLC (St. Louis, MO, USA) was used for this work. The manufacturer specifies a protein content of at least $90 \%$ on a dry basis. The contents of the minor ingredients are $\leq 1 \%$ fat and $\leq 5 \%$ ash. The moisture content of $3.4 \%(w / w)$ was determined gravimetrically. Commercial whey protein concentrate GermanProt 8000 was kindly provided by Sachsendorf Leppersdorf GmbH (Leppersdorf, Germany). According to the manufacturer, it has a protein content of at least $80 \%$ on a dry matter basis. The contents of the minor ingredients are $\leq 8.5 \%$ lactose, $\leq 6.5 \%$ fat and $\leq 4 \%$ ash. The gravimetrically determined moisture content was $5.4 \%(w / w)$.

\subsection{Extrusion Trials}

Extrusion trials were conducted using a co-rotating twin-screw with a screw diameter of $11 \mathrm{~mm}$ (Process 11, Thermo Fisher Scientific, Waltham, MA, USA). The length to diameter 
(L/D) ratio is 40 and a slit cooling die was attached to the extruder through a die adapter. Only forward elements were used in the screw configuration.

The extruder barrel consists of eight barrel elements. Besides the first barrel, all barrels can be heated and cooled independently. The die adapter can also be heated. Solids are dosed via a gravimetrically controlled feeder from Brabender Technology GmbH (Duisburg, Germany) in the first barrel element, and water is dosed via a peristaltic pump from Cole Parmer (Masterflex L/S, Vernon Hills, IL, USA) in the third barrel element. The die adapter is $32 \mathrm{~mm}$ long and provides a transition from the screw section to the cooling die. The cooling die $(125 \times 19 \times 4 \mathrm{~mm})$ was cooled with a temperature control liquid Thermal HL60 at $-10{ }^{\circ} \mathrm{C}$, which was supplied by a water-cooled process circulator Presto Plus LH 47, both from Julabo GmbH (Seelbach, Germany).

The screw speed was kept constant at $600 \mathrm{rpm}$ during the extrusion trials. A $0.9 \mathrm{~kg} / \mathrm{h}$ protein blend and $1.1 \mathrm{~kg} / \mathrm{h}$ water (tap water with a conductivity of $584.75 \pm 16.78 \mu \mathrm{S} / \mathrm{cm}$ from Karlsruhe, Germany) were always added. The SPI + WPC blends were premixed outside the extruder; for a WPC concentration of $15 \%, 0.135 \mathrm{~kg} / \mathrm{h} \mathrm{WPC}$ and $0.765 \mathrm{~kg} / \mathrm{h}$ SPI were added, for a WPC concentration of $30 \%, 0.27 \mathrm{~kg} / \mathrm{h} \mathrm{WPC} \mathrm{and} 0.63 \mathrm{~kg} / \mathrm{h}$ SPI were added. Taking into account the raw material moisture, this results in moisture contents of $56.5 \%$ (SPI), $56.7 \%$ (SPI + 15\% WPC) and 56.8\% (SPI + 30\% WPC) $(w / w)$ for the protein blends in the extrusion trials.

The temperature setting for the barrel elements 2 to 5 was: $T_{\text {Barrel, } 2}=25{ }^{\circ} \mathrm{C}$, $\mathrm{T}_{\text {Barrel }, 3}=50{ }^{\circ} \mathrm{C}, \mathrm{T}_{\text {Barrel }, 4}=90^{\circ} \mathrm{C}, \mathrm{T}_{\text {Barrel }, 5}=110{ }^{\circ} \mathrm{C}$. The barrel elements 6 to 8 and the die adapter were specifically adjusted to achieve one of the three desired material temperatures $\left(115,125,133^{\circ} \mathrm{C}\right)$ for each material system. The temperature profiles required for this are given in Table 1.

Table 1. Temperature profiles of the extrusion trials. Temperature of the barrels $6-8$ and the die adapter were specifically adjusted to achieve material temperatures of 115,125 and $133^{\circ} \mathrm{C}$ for each material system.

\begin{tabular}{c|c|c|c|c|c|c|c|c|c}
\hline $\mathbf{T}_{\text {Material }} /{ }^{\circ} \mathrm{C}$ & \multicolumn{3}{|c|}{115} & \multicolumn{3}{c|}{125} & \multicolumn{3}{c}{133} \\
mixture & & SPI + & SPI & & SPI + & SPI + & & SPI + & SPI + \\
& SPI & $\begin{array}{c}15 \% \\
\text { WPC }\end{array}$ & $\begin{array}{c}30 \% \\
\text { WPC }\end{array}$ & SPI & $\begin{array}{c}15 \% \\
30 \%\end{array}$ & WPC & WPC & SPI & $\begin{array}{r}15 \% \\
\text { WPC }\end{array}$ \\
\hline $\mathrm{T}_{\text {Barrel,6-8 and die }} /{ }^{\circ} \mathrm{C}$ & 133 & 138 & 138 & 144 & 149 & 150 & 155 & 159 & 160 \\
\hline
\end{tabular}

The material temperature and the die pressure were measured in the die adapter mounted prior to the cooling die. Sampling for further analysis was performed once the die pressure and material temperature were constant for at least three minutes. The pressure was then measured for three more minutes and averaged. To investigate the anisotropic product structure, the extrudates were torn open and photographed immediately after exiting the extruder. For further analysis, the extrudates were immediately vacuumed after exit, frozen and stored at $-18{ }^{\circ} \mathrm{C}$ until further use.

\subsection{Texture Analysis}

The textural properties of the extrudates were determined via cutting measurements, which are derived from previous work on HME $[12,39]$. The measurements were performed with a materials testing machine from Zwick\&Roell (zwickiLine Z2.5, Ulm, Germany). Before measurement, the extrudates were thawed at room temperature. Then rectangular pieces were punched out with a punch geometry $(8.5 \times 15 \mathrm{~mm})$, longitudinally and transversely to the flow direction. The punched pieces were then cut $3.8 \mathrm{~mm}$ deep $(95 \%$ of the extrudate thickness) along the long side with an in-house manufactured knife blade (A/LKB), at a cutting speed of $0.5 \mathrm{~mm} / \mathrm{s}$. The cutting force was recorded and the maximum cutting force was determined and selected as representative of the sample. Each cut per cutting direction and extrudate was repeated at least 12 times. The anisotropy index $(A I)$ 
was calculated from the ratio of the transversal cutting force $\left(\mathrm{F}_{\mathrm{T}}\right)$ to the longitudinal cutting force $\left(\mathrm{F}_{\mathrm{L}}\right): A I=\mathrm{F}_{\mathrm{T}} / \mathrm{F}_{\mathrm{L}}$.

\subsection{Cryo-Imaging}

The morphology of the extrudates was analysed by cryo-imaging [10]. For this purpose, the frozen samples were cut laterally to the flow direction (side view) with a cryo-microtome (CM 3050, Leica Biosystems GmbH, Nussloch, Germany). A cooling room temperature of $-14{ }^{\circ} \mathrm{C}$ and a sample holder temperature of $-12{ }^{\circ} \mathrm{C}$ were set for the instrument. To prepare the extrudates for cutting, $4-5 \mathrm{~cm}$ long sections were cut out from the extrudate strand. These sections were attached to the sample holder with a sectioning medium from Leica Biosystems GmbH (FSC 22 Frozen Section Media, Nussloch, Germany). This ensured product stability on the sample holder during sectioning and had no influence on the product microstructure. By cutting $40-\mu \mathrm{m}$ sections from the extrudate, smooth cut surfaces were obtained. Photos of the cut surface were taken immediately after cutting of the extrudate in the cryo-microtome with a digital camera (DMC-GH2, Lumix, Kadoma, Japan) and a $4608 \times 3456$ pixel resolution.

\subsection{Micro-CT}

The morphology of the extrudates was also analysed by measurements with a microcomputed tomograph (micro-CT) [10]. The preparation of samples for the X-ray measurements in the micro-CT was initiated by freeze-drying $5-6 \mathrm{~cm}$ sections of the extrudate strand with a lab-scale freeze-dryer from Martin Christ Gefriertrocknungsanlagen $\mathrm{GmbH}$ (Alpha 1-4 LDplus, Osterode, Germany) at $-80^{\circ} \mathrm{C}$ and $50 \mathrm{mbar}$ for at least $72 \mathrm{~h}$. The dried samples were then analysed with the Xradia 520 from Carl Zeiss Microscopy Deutschland $\mathrm{GmbH}$ (Oberkochen, Germany). The parameters of the measurements were: $0.4 \times$ objective, $2 \times$ binning, source filter: air, $50 \mathrm{kV}$ voltage, $4 \mathrm{~W}$ power. The exposure time was adapted for each extrudate and scanning position, depending on the measured transmittance, to ensure image quality, and varied between 0.8 and $2.4 \mathrm{~s}$. A full $360^{\circ}$-scan with 801 projections was performed.

\subsection{Rheological Measurements}

To determine the rheological properties of the proteins blends at extrusion-like conditions, samples were analysed in a closed cavity rheometer (CCR) from TA Instruments, Inc. (RPA flex, New Castle, DE, USA); see Figure 1. A detailed description of this instrument can be found elsewhere $[40,41]$; only a brief description should be given here. The sample (5.5-6.0 g) is initially placed between the two cones. Then, the upper cone moves downwards and applies a closing pressure. This creates a closed and pressurised cavity for the material and therefore prevents water evaporation at high temperatures. The rheological properties can then be calculated from the resulting force of the sinusoidal rotary deformation of the lower cone.

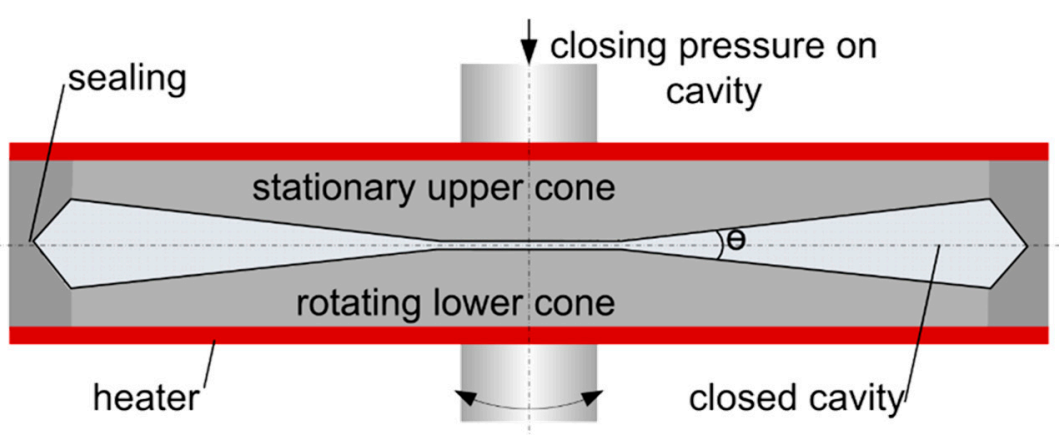

Figure 1. Closed cavity rheometer used for rheological characterisation of the material (picture taken from Emin and Schuchmann, 2017 [42]). 
For the dough preparation, solid SPI and WPC were first mixed at ratios of 100:0, 85:15 and 70:30, which resembles the 0,15 and 30\% of WPC in the material systems. The solid blends were then mixed with deionised water in a Thermomix from Vorwerk (Wuppertal, Germany) to achieve a moisture content of $55 \%(w / w)$ for all mixtures, taking into account the raw material moisture. The doughs were then vacuum sealed and stored in a refrigerator at $4{ }^{\circ} \mathrm{C}$ for at least $12 \mathrm{~h}$ prior to the measurements to ensure uniform water distribution and hydration.

The measurement routines were performed at three temperatures: 115, 125 and $133^{\circ} \mathrm{C}$. In each routine, the material was treated for $60 \mathrm{~s}$ at the desired temperature and a frequency of $1.0 \mathrm{~Hz}$ and $0.98 \%$ to ensure the constant temperature of the sample. The deformation parameters are well in the linear viscoelastic range (LVE) of the materials, where rheological properties are not stress or strain-dependent [43], and therefore no influence of the measurements mechanical treatment on the material is expected. Afterward, a strain sweep at the same desired temperature and a constant frequency of $1.0 \mathrm{~Hz}$ was performed. The strain increased gradually from $\gamma=0.9-1005 \%$. Storage modulus $G^{\prime}$ and loss modulus $\mathrm{G}^{\prime \prime}$ were determined as a function of strain $\gamma$.

\subsection{Scanning Electron Microscopy (SEM)}

The analysis of the phase behaviour and morphology of the whey proteins was performed with SEM measurements. For this purpose, materials were first treated in the CCR and afterward examined with the SEM. Doughs of SPI and SPI + 30\% WPC with a moisture content of $55 \%(w / w)$ were prepared as described for the rheological measurements.

For the determination of the influence of thermomechanical treatment, samples were treated at $125{ }^{\circ} \mathrm{C}$ for $60 \mathrm{~s}$ and an additional oscillatory deformation. For SPI, only an oscillatory deformation in the LVE at $1.0 \mathrm{~Hz}$ and $0.98 \%$ was performed, which equals and will be described as " $0 \mathrm{~s}^{-1}$ ". For SPI $+30 \%$ WPC, three different oscillatory deformations were applied: $1.0 \mathrm{~Hz}$ and $0.98 \%\left(0 \mathrm{~s}^{-1}\right), 10.0 \mathrm{~Hz}$ and $120 \%$ (which equals $75 \mathrm{~s}^{-1}$ ) and $10.0 \mathrm{~Hz}$ and $240 \%\left(150 \mathrm{~s}^{-1}\right)$. After the one-minute treatment, the material was cooled to $90{ }^{\circ} \mathrm{C}$ in the CCR, the cavity opened and the pellet was taken out.

For the determination of the influence of singular rotatory shear deformation, samples from SPI $+30 \%$ WPC were treated at $125^{\circ} \mathrm{C}$ for $60 \mathrm{~s}$ and an oscillatory deformation in the LVE at $1.0 \mathrm{~Hz}$ and $0.98 \%$. Afterward, the material was cooled to $90{ }^{\circ} \mathrm{C}$. At $90{ }^{\circ} \mathrm{C}$, the material was deformed in a continuously rotatory way, with a constant strain of $5000 \%$ (which is almost a $360^{\circ}$ rotation) but at different deformation times. A decrease in time means an increase in the shear rate. Deformation times of $200 \mathrm{~s}\left(0.25 \mathrm{~s}^{-1}\right), 50 \mathrm{~s}\left(1 \mathrm{~s}^{-1}\right), 20 \mathrm{~s}$ $\left(2.5 \mathrm{~s}^{-1}\right)$ and $5 \mathrm{~s}\left(10 \mathrm{~s}^{-1}\right)$ were applied. After this deformation, the cavity was opened and the pellet was retained. The formation of this pellet from raw material dough is shown in a recent study [38].

The pellets from both routines were prepared for the SEM measurements by predrying for at least $72 \mathrm{~h}$ at $25^{\circ} \mathrm{C}$ in room air, and subsequently by vacuum-drying for at least $72 \mathrm{~h}$ at $25^{\circ} \mathrm{C}$ and $10 \mathrm{mbar}$. To reveal the inner structure of the pellet, these pellets were broken at a defined distance of $2 \pm 0.1 \mathrm{~mm}$ from the outside radius, as shown in Figure 2.

To prepare the fractured surface for SEM measurement, a high vacuum sputter coater from Leica Microsystems GmbH (EM ACE 600, Wetzlar, Germany) applied a $7 \mathrm{~nm}$ platinum coating and the coating was contacted with conductive silver. The SEM measurements were performed with an environmental scanning electron microscope from FEI (Quanta 650 FEG, Eindhoven, The Netherlands), using secondary electrons, topographical contrast and an Everhart-Thornley detector. 


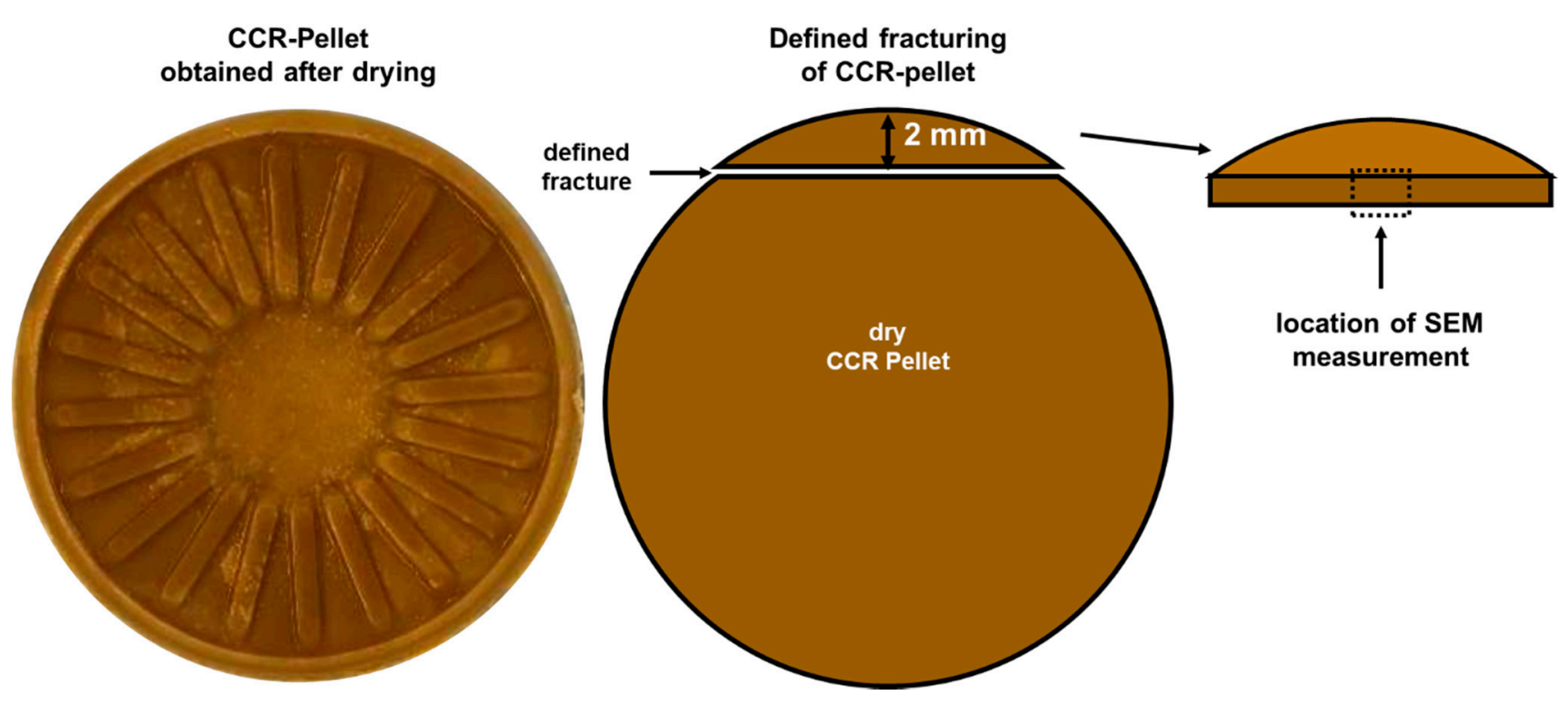

Figure 2. Sketch of the process of preparing the CCR-pellets for SEM measurements.

\section{Results and Discussion}

3.1. Influence of Protein Blending on Process Conditions

The die pressure values for the different protein blends are plotted above the material temperature at the extruder die in Figure 3. The lines between the points were drawn to guide the eye. Total mass flow and die geometry were kept constant in these trials.

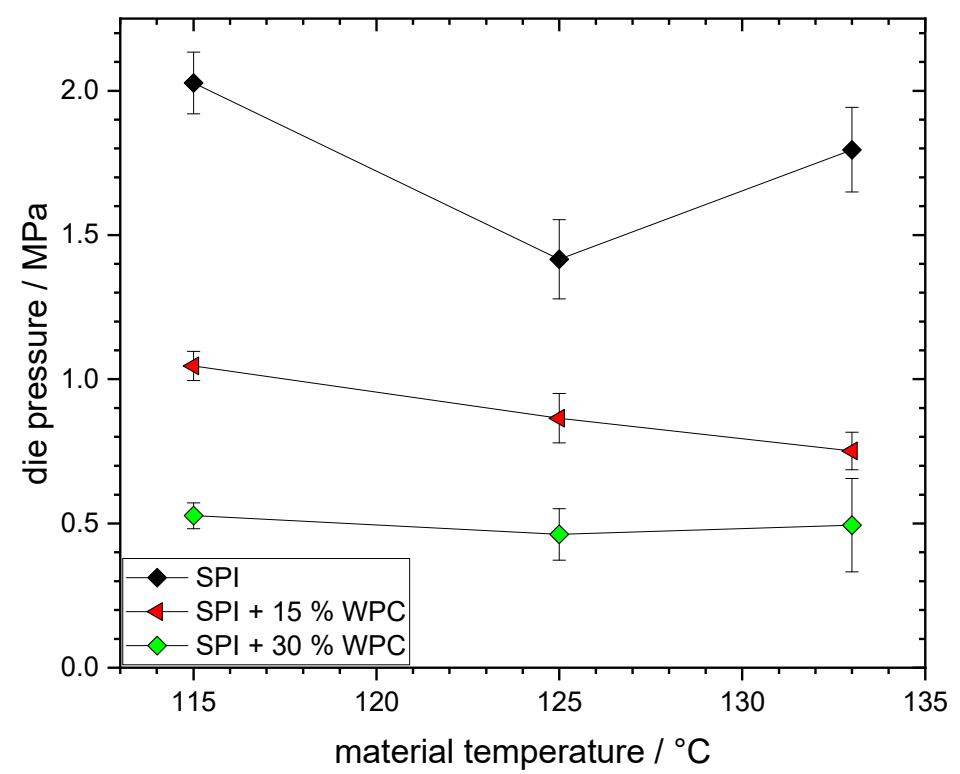

Figure 3. Die pressure as a function of material temperature for different protein blends (0-30\% WPC).

The addition of WPC has a distinct effect on the die pressure: an increase in WPC concentration results in a decrease in die pressure. For SPI, the values range from $1.4 \mathrm{MPa}$ at $125^{\circ} \mathrm{C}$ to $2.0 \mathrm{MPa}$ at $115^{\circ} \mathrm{C}$. With $15 \% \mathrm{WPC}$, the die pressure reaches a range of 0.8 to 1.0 $\mathrm{MPa}$. At 30\% WPC, the die pressure is constant at about $0.5 \mathrm{MPa}$.

As the total mass flow and the die geometry are kept constant, the die pressure is a direct function of the viscosity of the material. Thus, the reduction in pressure due to the addition of WPC indicates a reduction in viscosity. This could be due to two effects: firstly, a mixing effect when the rheological properties of the mixture are a simple combination of 
those of the individual components WPC and SPI. Secondly, a dispersed phase could have been formed, which influences the rheological properties through a "weakening" of the overall structure ("dispersed phase effect"). This effect of a dispersed phase is known, for example, in polymer blends [44], where even small amounts of a second polymer change the rheological properties beyond the mixing effect.

The reduction in pressure with increasing temperature, as occurs at SPI between $115^{\circ} \mathrm{C}$ and $125^{\circ} \mathrm{C}$ and at SPI $+15 \%$ WPC for all three temperatures, can be explained by a reduction in viscosity due to increased mobility of the molecules [45]. At least a small reduction in die pressure would have been expected at SPI $+30 \%$ WPC; thus, this expected viscosity reduction must have been outweighed by some other effect. Whey proteins are known to be reactive and aggregate at extrusion conditions [46,47], leading to an increase in viscosity [48], which could be such an overlying effect. Reactivity could also be considered for the pressure increase at $133{ }^{\circ} \mathrm{C}$ in SPI. However, Wittek et al. [10] have shown that the present SPI is not reactive at comparable extrusion conditions. Thus, the reason for the pressure increase with SPI remains unclear.

\subsection{Influence of Protein Blending on Product Structure and Texture}

The product structure of the extrudates for the different material temperatures and WPC concentrations can be seen in Figure 4.

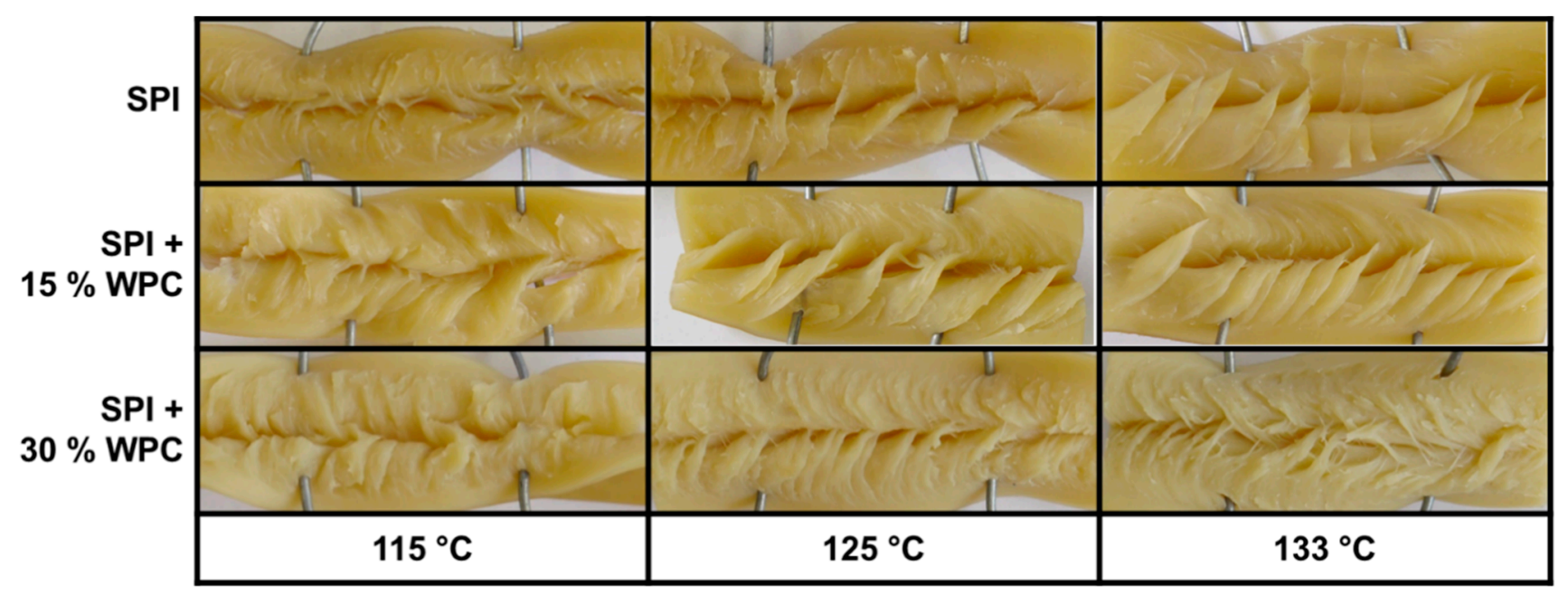

Figure 4. Product structure of extrudates for different protein blends (0-30\% WPC) and material temperatures $\left(115-133{ }^{\circ} \mathrm{C}\right)$.

An anisotropic structure was formed for all protein blends at all investigated process conditions. The ability of sole SPI to form anisotropic structures in HME has already been demonstrated under comparable conditions $[10,12]$, as well as for blends of SPI and WPC [49].

The addition of $15 \%$ WPC leads to a more pronounced anisotropic product structure for all three material temperatures. The effect of blending protein-rich raw materials on the product structure and/or anisotropy has already been reported [1,18].

Further increase in the WPC concentration to $30 \%$ also has an effect on the anisotropic structure. In this case, the anisotropic structures are more pronounced than with SPI, and the structures are thinner than in SPI + 15\% WPC. Park et al. [15] demonstrated that increasing wheat gluten content improved the textural properties of extruded SPI, but it is not reported how the underlying anisotropic structures developed.

An increase in the material temperature leads to a more pronounced anisotropic structure in all three protein blends. In a study with the same SPI and comparable process conditions [10], it was suggested that this was due to the dependence of the rheological properties on temperature [45]. 
The textural properties of the extrudates, i.e., longitudinal force and anisotropy index $(A I)$, can be seen in Figure 5. The lines between the points were drawn to guide the eye.
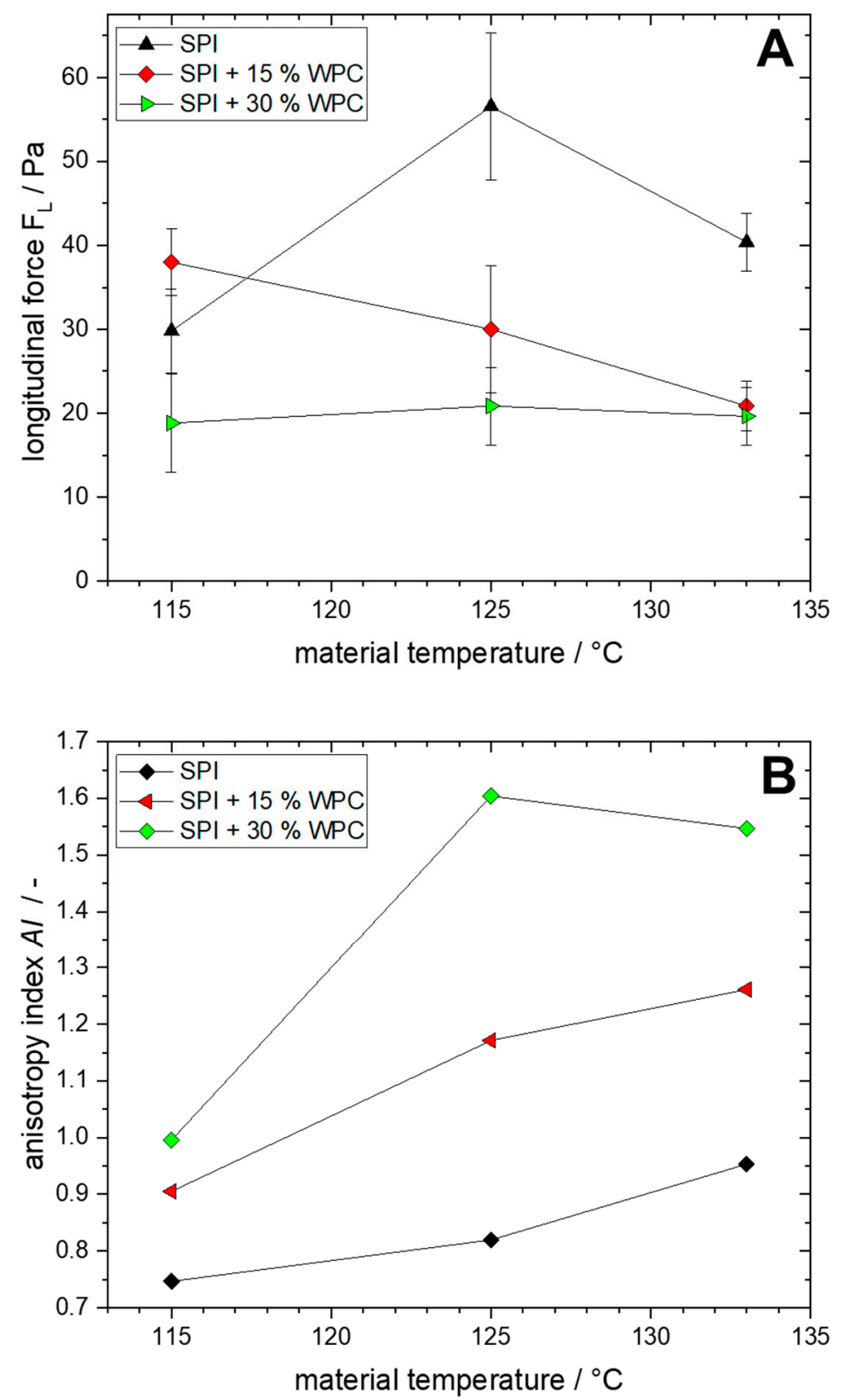

Figure 5. Longitudinal force (A) and anisotropy index $A I(\mathbf{B})$ as a function of material temperature for different protein blends (0-30\% WPC).

For both parameters, the influence of WPC addition can be clearly seen. For the longitudinal cutting force, no clear correlation to the WPC concentration is apparent at $115^{\circ} \mathrm{C}$, it ranges from 19 to $38 \mathrm{~Pa}$. However, at $125^{\circ} \mathrm{C}, 15 \%$ WPC leads to a reduction of the cutting force from 57 to $30 \mathrm{~Pa}$, while at $30 \% \mathrm{WPC}$, it is only $21 \mathrm{~Pa}$. For $133{ }^{\circ} \mathrm{C}$, the cutting force also decreases due to WPC addition, from $40 \mathrm{~Pa}$ to $21 \mathrm{~Pa}$ with SPI $+15 \% \mathrm{WPC}$ and $20 \mathrm{~Pa}$ with SPI $+30 \%$ WPC.

With increasing temperature, no distinct trend can be seen: for SPI, the cutting force first increases and then decreases. For SPI + 15\% WPC, the cutting force decreases with increasing temperature, while for SPI $+30 \%$ WPC it remains almost constant.

For the anisotropy index $(A I)$, as for the longitudinal cutting force, the large influence of the WPC addition is apparent. As the WPC concentration increases, the $A I$ increases, with a smaller relative increase at $115{ }^{\circ} \mathrm{C}$ (from 0.75 to 0.91 to 1.0 ) than at $125^{\circ} \mathrm{C}(0.82$ to 
1.17 to 1.60$)$ and at $133{ }^{\circ} \mathrm{C}(0.95$ to 1.26 to 1.54$)$. Likewise, the $A I$ increases with increasing temperature, except for the step from $125{ }^{\circ} \mathrm{C}$ to $133{ }^{\circ} \mathrm{C}$ at SPI $+30 \% \mathrm{WPC}$, where it decreases slightly.

Different studies on HME have also used cutting tests to characterize the textural properties, but a comparison of the absolute values for the cutting values is hardly possible, since the measurement parameters, such as blade sharpness, were not the same. However, the $A I$ can be compared, since here the measurement setup-specific influences are eliminated.

For the extrusion of three different pea protein isolates, it could be shown as well that the $A I$ is influenced by the material temperature [39]. For extruded soy protein concentrate, the $A I$ was found to be 1.04 [50], and for blends of peanut protein, SPI, and wheat gluten in various ratios, the $A I$ ranged from 0.91 to 1.06 [17]. For single-component SPI, $A I$ ranged from circa 0.9 to 1.2 at different process conditions [12]. Thus, these values are comparable to those obtained in this work for SPI and SPI $+15 \%$ WPC, but considerably higher $A I$ (1.54 and 1.60) are obtained for SPI + 30\% WPC.

The texture measurements as a method to quantitatively describe the anisotropy of the products also correlates with the visual appearance of the anisotropic structures from Figure 4. With increasing WPC concentration and temperature, the structure becomes more pronounced and thinner, which is also reflected in the increase in $A I$.

\subsection{Morphology Development in Extrudates}

The morphology development in the extrudates, visualised by cryo-imaging, can be seen in Figure 6. The flow direction is from left to right.

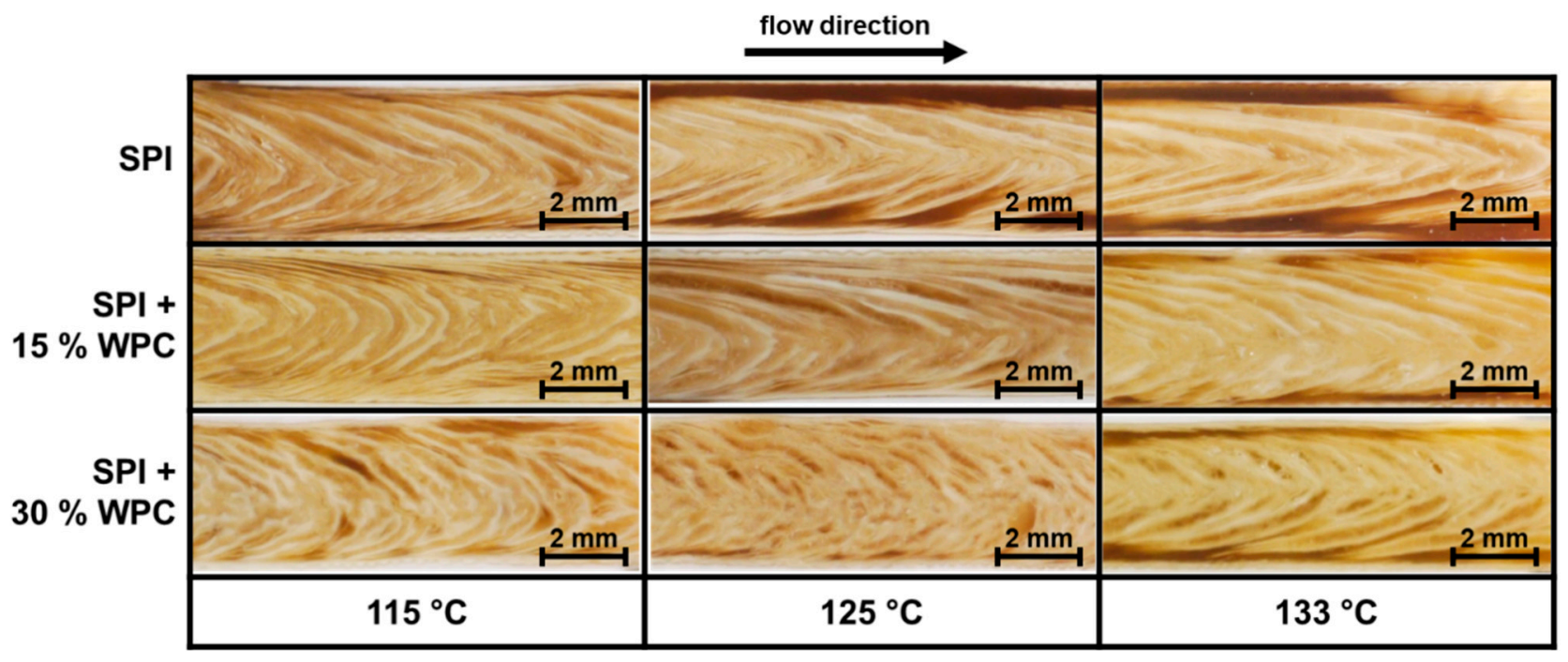

Figure 6. Multi-phase morphology, obtained through cryo-imaging of extrudates for different protein blends (0-30\% WPC) and material temperatures $\left(115-133^{\circ} \mathrm{C}\right)$.

All extrudates show a clearly visible multiphase system, with the phases differing in color and brightness. The phases are always deformed in the direction of flow, as already shown by Wittek et al. [10], and have the shape of an assumed flow profile. In the following, this shape will be called the "V-shape". The individual enclosed structures themselves exhibit a high degree of anisotropy, i.e., they are significantly longer than they are wide (L/D > 5).

The addition of $15 \%$ WPC has only a minor effect on the morphology, with the structures becoming slightly thinner. When increasing to $30 \% \mathrm{WPC}$, the influence is more pronounced. The structures are more disordered, shorter and thinner than with the other two WPC concentrations. In addition, as the WPC concentration increases, the angle of the V-shape decreases. 
Temperature also has a significant effect on morphology. For all three WPC concentrations, the angle of the V-shape increases with increasing temperature.

The multiphase morphology of the freeze-dried extrudates for a material temperature of $125^{\circ} \mathrm{C}$, visualised by micro-CT, can be seen in Figure 7 . The flow direction is from left to right.

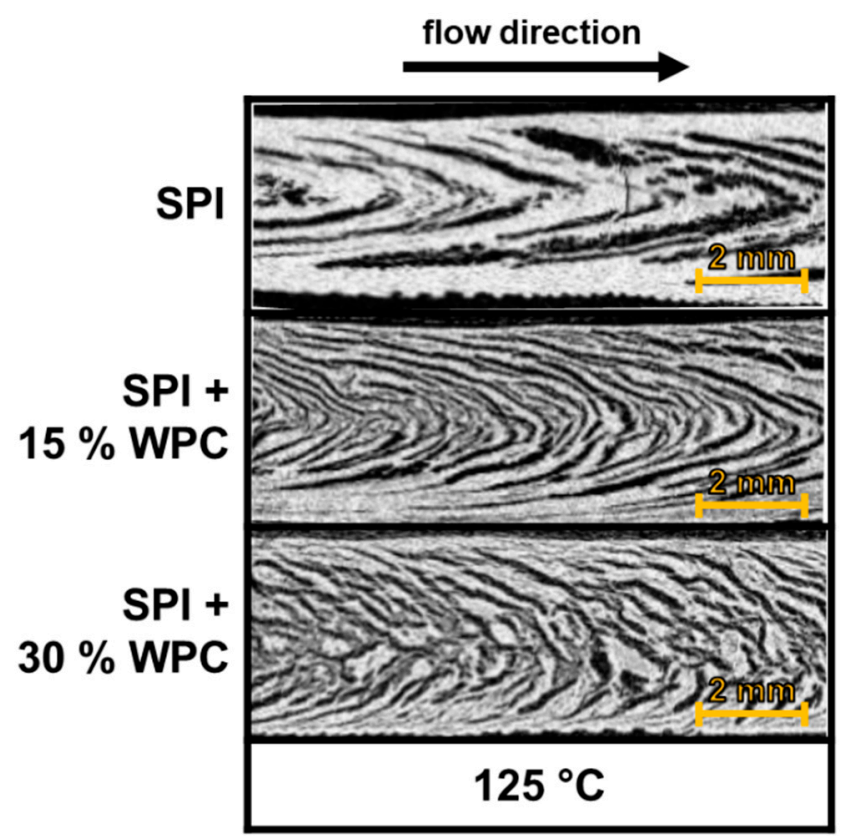

Figure 7. Multi-phase morphology, obtained through micro-CT of freeze-dried extrudates, for different protein blends (0-30\% WPC) and material temperature of $125^{\circ} \mathrm{C}$.

The dark areas indicate low density, while the light areas indicate high density, relatively speaking. The morphology shown here is almost identical to that from cryo-imaging (Figure 6). The characteristic V-shape can be seen for all three WPC concentrations and the angle of the V-shape decreases with increasing WPC concentration. In addition, as seen in the cryo-imaging images, the (dark) dispersed phase be.

The multiphase system arises as a result of the thermodynamic incompatibility of the proteins [24]. As discussed in earlier work from us [10], the results indicate that a water-rich dispersed phase is present and distributed in a water-poor continuous phase. The distribution of water can be attributed to the different hydrophilicities of the proteins involved [26]. Since proteins of different origins differ in their amino acid composition [32], it is also expected that the added whey protein, or its fractions (ß-lactoglobulin, $\alpha$-lactalbumin, etc.), will have different hydrophilicity than the present soy protein fractions. Consequently, the WPC addition must also have a direct influence on the water distribution in the system and so on the water concentration in the individual phases.

Thus, an influence on the morphology development would also be given, since this depends, e.g., via the viscosity ratio, on the rheological properties of the phases involved, which in turn are a function of the particular phase water concentration.

The changes of the rheological properties of the individual phases through the water distribution are a very likely explanation for the differences in the morphology development, as they would strongly affect the deformation forces acting on the phases. However, another effect might have played an additional role; the decreasing die pressure values with increasing WPC concentration suggest that the added WPC also causes a direct influence on the rheological properties of the overall system, as already discussed, for example, via the mixing effect or the dispersed phase effect. This might also influence morphology development. 


\subsection{Influence of Protein Blending on Rheological Properties}

The rheological properties of the protein blends with different WPC concentrations were characterised by means of strain sweeps at the different material temperatures of the extrusion trials. The results can be seen in Figure 8, where $G^{\prime}$ and $G^{\prime \prime}$ are plotted above the strain, respectively.

For almost all investigated protein blends and temperatures, a plateau of $\mathrm{G}^{\prime}$ is visible for low strains. From a certain point, which marks the end of the LVE, $\mathrm{G}^{\prime}$ drops sharply; this marks the beginning of the non-linear viscoelastic range (nLVE). The rheological behaviour in the nLVE was suggested to be relevant for the behaviour in the extrusion process, where high shear rates (and thus high strains) occur [41,51].

For the curve of $G^{\prime \prime}$, all materials show a so-called "weak strain overshoot": that is, an increase in $G^{\prime \prime}$, reaching a maximum, and then the decrease in $G^{\prime \prime}$. This behaviour was shown for different highly concentrated biopolymers [41,51,52] and may have different causes; however, a clear structural interpretation is difficult [53] and will not be further discussed here.

In the LVE of $G^{\prime}$, i.e., for low strains, $G^{\prime}$ and $G^{\prime \prime}$ increase with increasing WPC concentration. This behaviour is apparent for all temperatures. The range of LVE decreases with increasing WPC concentration. In the nLVE, i.e., for high strains, the trends reverse for 115 and $125^{\circ} \mathrm{C}$, i.e., the $\mathrm{G}^{\prime}$ decreases with increasing WPC concentration. For $133^{\circ} \mathrm{C}$, the curves then line up. Similar trends as for $\mathrm{G}^{\prime}$ can also be observed for $\mathrm{G}^{\prime \prime}$ in the nLVE.

These differences in the behaviour of a material in the LVE and nLVE have already been observed in multiphase polymer blends [54]. Generally, the rheological properties of a blend are related to the morphology of the dispersed phase(s). When the strain of a measurement affects the morphology (which occurs at sufficiently high strain), the rheological properties also change. This can be demonstrated with an example: in a polymer blend of EPDM rubber (ethylene propylene diene monomer rubber) with poly(vinylideneco-hexafluoropropylene), the addition of the second polymer resulted in a significant reduction in shear viscosity in a steady-shear flow field (capillary rheometer) [44], but similar values of complex viscosity were achieved in the LVE through dynamic-oscillatory measurements [55]. The results thus suggest that the WPC has formed a dispersed phase in the extrudate, which triggers the observed rheological behaviour.

The influence of the high strains during the measurements in the nLVE on the phase morphology explains why the increase in $G^{\prime}$ and $G^{\prime \prime}$ in the LVE through WPC-addition is reversed in the nLVE. Since the rheological behaviour in the nLVE is more representative of the material behaviour in the extruder [51], the lower die pressure, ergo the lower viscosity, can also be explained by the addition of WPC. For the significantly higher shear rates in the extrusion process and in the screw section, respectively, it is expected that the $\mathrm{G}^{\prime} / \mathrm{G}^{\prime \prime}$-reducing effect due to the addition of WPC is more pronounced.

It is expected that the influence of the WPC addition on the rheological properties of the overall system also has an effect on the morphology development, because, as already mentioned, it strongly depends on the rheological properties [56]. However, only a general statement can be made here. Although the rheological properties of the overall system (continuous and dispersed phase together) can be determined with the methodology used, the viscosity ratios of the phases in the extrudates remain unknown. 

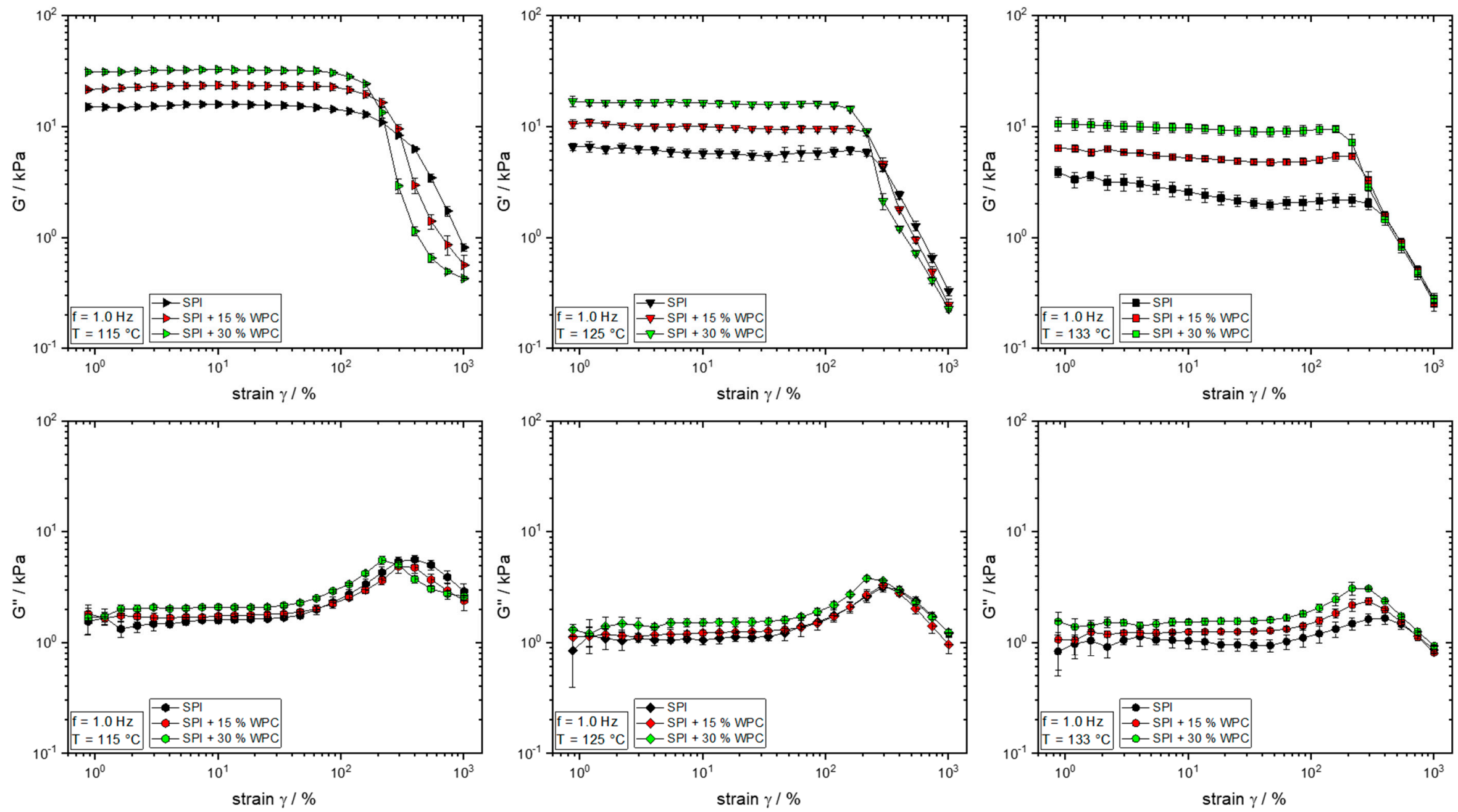

Figure 8. Storage modulus $\mathrm{G}^{\prime}$ and loss modulus $\mathrm{G}^{\prime \prime}$ as a function of strain $\gamma$ for different protein blends $\left(0-30 \%\right.$ WPC) and temperatures $\left(115-133^{\circ} \mathrm{C}\right)$. 


\subsection{Phase Behaviour and Morphology of Whey Protein}

The rheological measurements suggest that the WPC has formed a dispersed phase. In the images from the cryo-imaging, it can be seen that the WPC has an effect on the morphology, but not whether and how it is present as a dispersed phase. However, the morphology has not changed fundamentally, i.e., no "new" dispersed phase on the size of the apparent dispersed water-rich phase was formed. Therefore, it was concluded that if the WPC did form a dispersed phase, it would have to be significantly smaller than the over-lying water-rich dispersed phase and thus not visualisable by cryo-imaging.

Therefore, SPI and the blend of SPI $+30 \%$ WPC were subjected to defined thermomechanical stress in a CCR at extrusion-like conditions (temperature, water content), and the resulting pellet was examined by scanning electron microscopy (SEM). In the first step, the mixture was only to be thermally treated in order to obtain the largest possible dispersed WPC phase, which would facilitate visualisation and serve as a starting and comparison point. Only in the second step, mechanical stress was applied in order to be able to investigate its influence in comparison with the sample treated only thermally. The results of SEM measurements are shown in Figure 9.

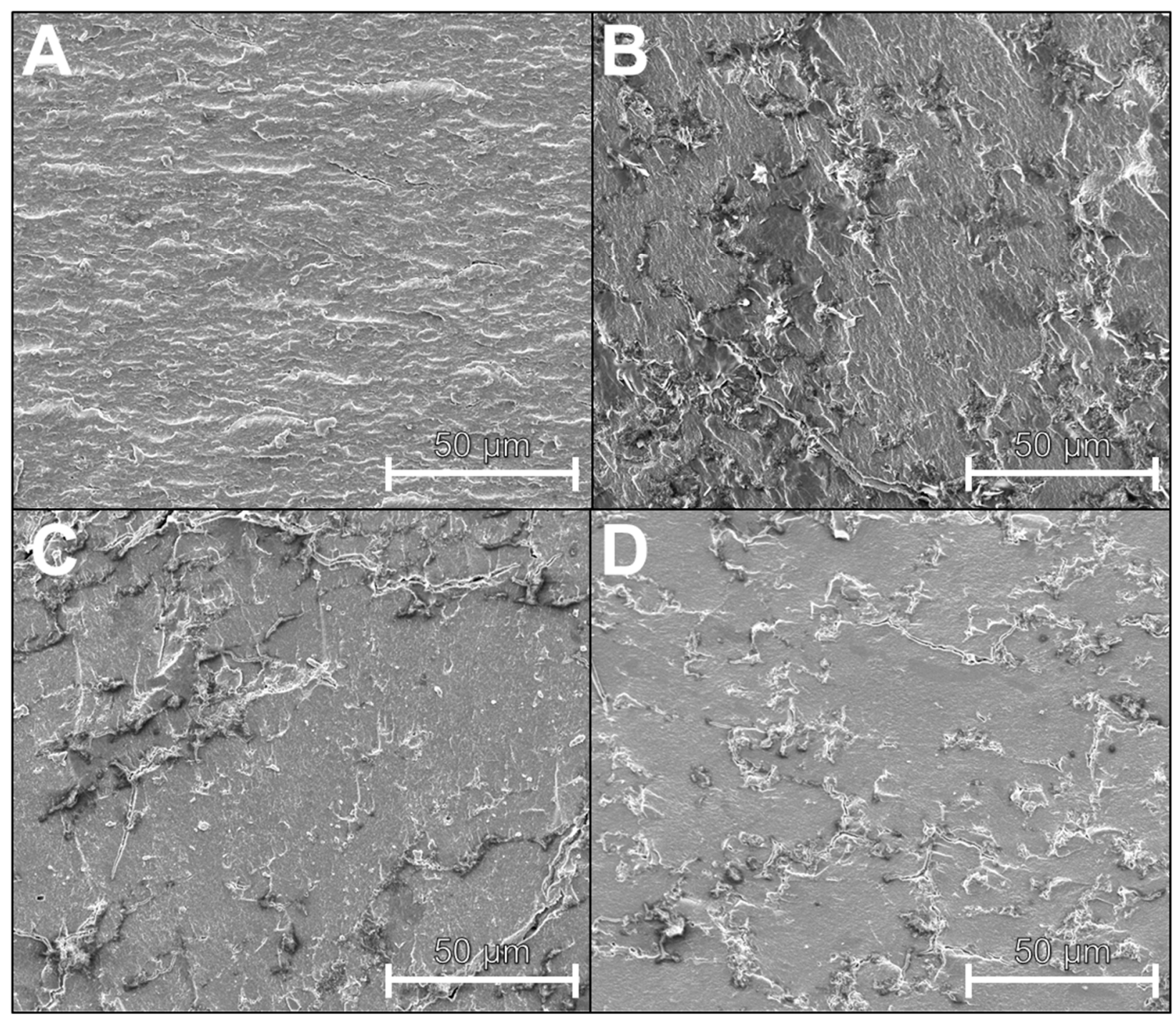

Figure 9. SEM-images of pellets, which underwent defined, extrusion-like thermomechanical treatment at $125{ }^{\circ} \mathrm{C}$ and different shear rates $\left(0,75,150 \mathrm{~s}^{-1}\right)$ in the CCR. (A) SPI, $0 \mathrm{~s}^{-1}$; (B) SPI + 30\% WPC, $0 \mathrm{~s}^{-1}$; (C) SPI + 30\% WPC, $75 \mathrm{~s}^{-1}$; (D) SPI $+30 \% \mathrm{WPC}, 150 \mathrm{~s}^{-1}$. 
In A, the pellet only consists of SPI. An irregular surface in a light grey tone can be seen. The roughness is due to the fracturing of the pellets. After the addition of $30 \% \mathrm{WPC}$, dark spots or shapes in the order of 1-20 $\mu \mathrm{m}$ can be seen, distributed in a light matrix (B). It can be assumed that the lighter constituent is the SPI and the dark/black shapes are formed by the WPC, thus showing that a dispersed WPC phase was created.

In $C$ and $D$ the effect of additional mechanical stress on the mixture is shown. The size of the dispersed WPC phase decreases with increasing shear rate and reaches a size of $<10 \mu \mathrm{m}$ for $150 \mathrm{~s}^{-1}$. It can therefore be assumed that this dark, dispersed WPC phase is broken up by the mechanical stresses.

This sensitivity of the WPC phase on mechanical stresses also has implications for the extrusion process. In the screw section, even higher shear rates occur than in the CCR. Shear rates of up to $5000 \mathrm{~s}^{-1}$ are reported $[57,58]$. Thus, it can be expected that the dispersed WPC phase will be even more broken up and sizes of $<1 \mu \mathrm{m}$ can be reached. As a result, the dispersed WPC phase would be much smaller than the over-lying dispersed water-rich phase that dominates the morphology in the cryo-imaging images (Figure 6).

In order to better understand the morphology development of the dispersed WPC phase, the system of SPI $+30 \%$ WPC was cooled down to $90{ }^{\circ} \mathrm{C}$ after a defined thermal treatment at $125{ }^{\circ} \mathrm{C}$ and a singular rotatory deformation at different defined shear rates was applied. Cooling simulates the extrusion process, where the material is also first heated, then cooled in the die section, and subsequently subjected to laminar flow, which exhibits much smaller shear rates than the screw section; apparent shear rates of 1.1-46 s ${ }^{-1}$ were calculated for the die section in various works on HME [59]. In the present work, an apparent shear rate between 8.6 to 10.9 can be calculated according to Son [60], depending on whether the outer rounded part of the flow channel is considered in the calculation or not. It should be mentioned that shear rates are not constant across the cross-section, but have a distribution that depends on the velocity gradients; they can be much smaller or higher than calculated [61].

The influence of the shear rate of a singular deformation on the morphology of the dispersed WPC phase can be seen in Figure 10.

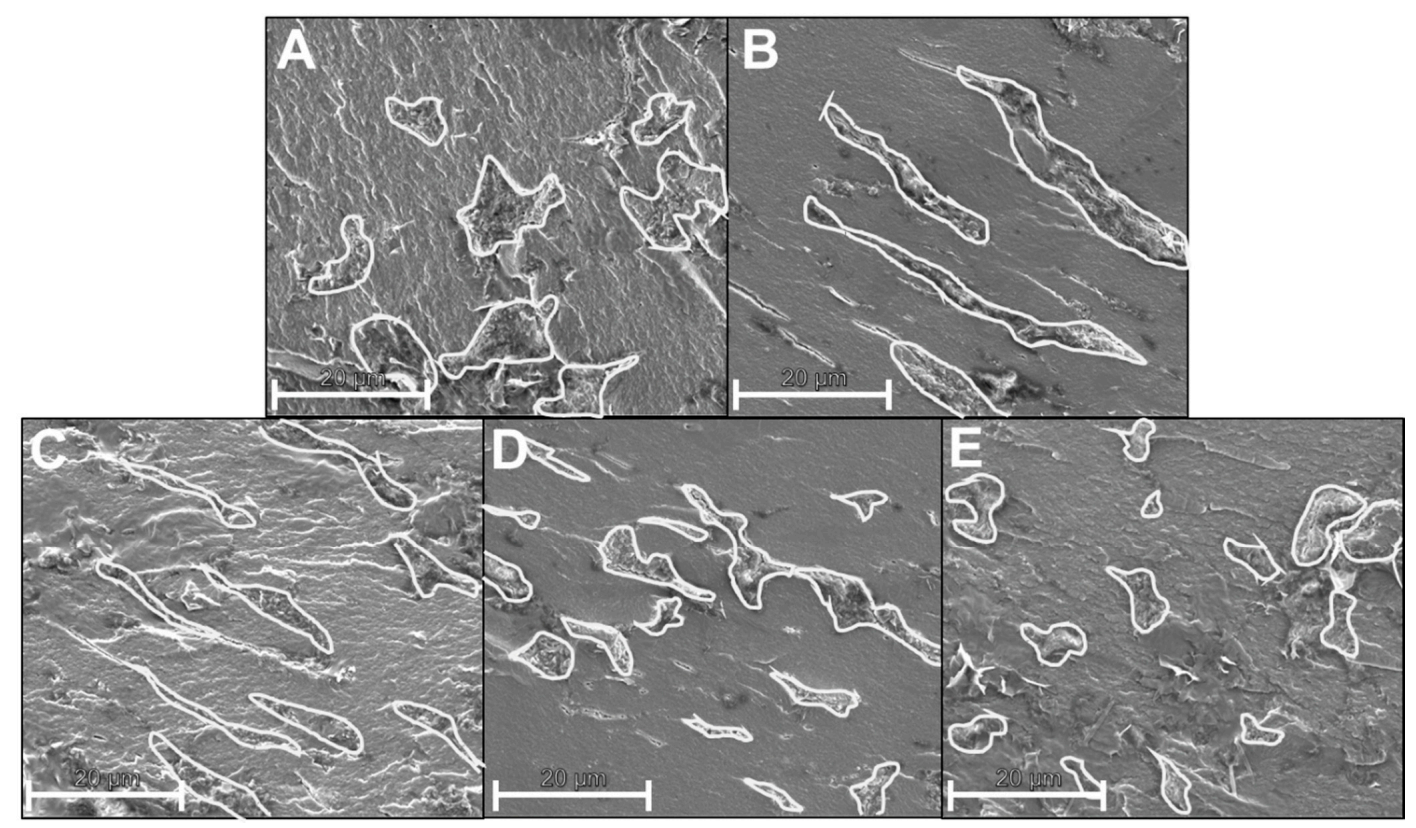

Figure 10. SEM-images of pellets from SPI $+30 \%$ WPC, which underwent a defined, extrusion-like thermal treatment at $125^{\circ} \mathrm{C}$, were cooled to $90{ }^{\circ} \mathrm{C}$ and then deformed for a given shear rate in the CCR: (A) $0 \mathrm{~s}^{-1}$, (B) $0.25 \mathrm{~s}^{-1}$, (C) $1 \mathrm{~s}^{-1}$, (D) $2.5 \mathrm{~s}^{-1}$, (E) $10 \mathrm{~s}^{-1}$. 
The dispersed phase was outlined with bright lines to improve visibility. At a shear rate of $0 \mathrm{~s}^{-1}$, the dispersed phase has a relatively compact, roundish shape. At $0.25 \mathrm{~s}^{-1}$, the phase begins to deform and forms an elongated shape oriented in the direction of deformation. As the shear rate continues to increase $\left(1 \mathrm{~s}^{-1}\right)$, the dispersed phase retains its elongated, aligned shape. At $2.5 \mathrm{~s}^{-1}$, however, shapes develop that are still deformed and aligned, but shorter than at $1 \mathrm{~s}^{-1}$. With still further increasing shear rate $\left(10 \mathrm{~s}^{-1}\right)$, an elongated shape is no longer evident, but more compact and visibly smaller shapes than in the initial situation at $0 \mathrm{~s}^{-1}$.

The results thus indicate that with increasing shear rate, the dispersed WPC phase first adopts a deformed shape, but with further increasing shear rate it is then broken up.

This behaviour has already been demonstrated for different polymer blends, e.g., by Hanafy et al. [62] with a 70:30 blend of polycarbonate and styrene-co-acrylonitrile random copolymer: a deformed shape of the dispersed phase and then a breakup could be observed with increasing shear rate.

For the extrusion process, the results imply that the thermomechanical stress can not only lead to a break-up and thus to a comminution of the dispersed WPC phase, but also to a deformed, elongated shape of the dispersed WPC phase. This deformed shape was also detected, for example, in SPI-pectin blends treated by the shear cell [63] and could be attributed to the low interfacial tension in the system.

Overall, it is assumed that due to the high shear rates and the inhomogeneous flow field in the screw section, the dispersed WPC phase is broken up and arrives as very small particles $(<1 \mu \mathrm{m})$ in the die section. Due to the laminar flow field in the die section, these small particles could then deform and align themselves in the flow direction, analogous to the shape of the overlying water-rich dispersed phase. However, depending on the shear rate, this could also lead to further breakup.

This insight into the size of the dispersed WPC phase leads to the assumption that the effect of WPC on the over-lying multiphase morphology is rather an indirect effect by being finely dispersed throughout the extrudate, and interacting with the morphology of the multiphase system by influencing the rheological properties and water distribution.

Nevertheless, the morphology of this small dispersed WPC phase could also play a certain role, as it can affect the rheological behaviour of the blend. For instance, Filipe et al. [64] have shown for polymer blends that a system with a deformed, non-round dispersed phase exhibits different rheological properties than the same system with a round dispersed phase.

\section{Conclusions}

The addition of WPC as a model protein in two different concentrations had a significant influence on high moisture extrusion processing and the resulting extrudates. With increasing WPC concentration, the anisotropic structures became more pronounced, the cutting force decreased and the $A I$ increased. The achieved $A I$ values were comparable to values from the literature, with SPI $+30 \%$ WPC yielding even higher $A I$ values. The die pressure in the process decreased significantly with increasing WPC content, suggesting that WPC addition led to lower blend viscosity. The multiphase morphology was distinctively affected by the WPC addition. The structures became thinner and were more evenly distributed; the apparent V-shape caused by the laminar flow in the die section was preserved but had a flatter angle. In the SPI matrix, the WPC forms a dispersed phase, the morphology of which depends on the (thermo-)mechanical stresses. Since the WPC dispersed phase is significantly smaller than the over-lying structure of the SPI (water-rich dispersed phase and water-poor continuous phase), it is assumed that the WPC acts on the multiphase morphology via influencing the rheological properties and the water distribution.

These findings show that the blending of protein-rich raw materials has the potential of tailoring the product structure of extruded meat analogues. The blending of materials from plant and animal origins, besides its advantages on the nutritive value and sensorial 
properties, can also improve the texture of meat analogues. Raw material selection for blending should be based on how rheological properties and water distribution are affected.

Author Contributions: Conceptualization, P.W. and M.A.E.; methodology, P.W.; validation, P.W.; investigation, P.W.; writing—original draft preparation, P.W.; writing—review and editing, M.A.E. and H.P.K. All authors have read and agreed to the published version of the manuscript.

Funding: This research project was supported by the German Ministry of Economics and Energy (via AiF) and FEI (Forschungskreis der Ernährungsindustrie e.V., Bonn) in the scope of project AiF 20249 N. The APC was funded by the KIT-Publication Fund of the Karlsruhe Institute of Technology.

Institutional Review Board Statement: Not applicable.

Informed Consent Statement: Not applicable.

Acknowledgments: The authors gratefully thank Kerstin Sauther, Nina Weis, Tobias Behrendt, Volker Zibat, Lea Fels and Benjamin Radel for supporting the sample preparation and analyses.

Conflicts of Interest: The authors declare no conflict of interest. The funders had no role in the design of the study; in the collection, analyses, or interpretation of data; in the writing of the manuscript, or in the decision to publish the results.

\section{References}

1. Cheftel, J.C.; Kitagawa, M.; Quéguiner, C. New protein texturization processes by extrusion cooking at high moisture levels. Food Rev. Int. 1992, 8, 235-275. [CrossRef]

2. Akdogan, H. High moisture food extrusion. Int. J. Food Sci. Nutr. 1999, 34, 195-207. [CrossRef]

3. Kitabatake, N.; Mégard, D.; Cheftel, J.C. Continuous Gel Formation by HTST Extrusion-Cooking: Soy Proteins. J. Food Sci. 1985, 50, 1260-1265. [CrossRef]

4. Gwiazda, S.; Noguchi, A.; Saio, K. Microstructural studies of texturized vegetable protein products: Effects of oil addition and transformation of raw materials in various sections of a twin screw extruder. Food Struct. 1987, 6, 57-61.

5. ISOBE, S.; Noguchi, A. High moisture extrusion with twin screw extruder-Fate of soy protein during the repetition of extrusion cooking. Nippon. Shokuhin Kogyo Gakkaishi 1987, 34, 456-461. [CrossRef]

6. $\quad$ Pietsch, V.L.; Werner, R.; Karbstein, H.P.; Emin, M.A. High moisture extrusion of wheat gluten: Relationship between process parameters, protein polymerization, and final product characteristics. J. Food Eng. 2019, 259, 3-11. [CrossRef]

7. Pietsch, V.L.; Emin, M.A.; Schuchmann, H.P. Process conditions influencing wheat gluten polymerization during high moisture extrusion of meat analog products. J. Food Eng. 2017, 198, 28-35. [CrossRef]

8. Kendler, C.; Duchardt, A.; Karbstein, H.P.; Emin, M.A. Effect of Oil Content and Oil Addition Point on the Extrusion Processing of Wheat Gluten-Based Meat Analogues. Foods 2021, 10, 697. [CrossRef]

9. Ferawati, F.; Zahari, I.; Barman, M.; Hefni, M.; Ahlström, C.; Witthöft, C.; Östbring, K. High-Moisture Meat Analogues Produced from Yellow Pea and Faba Bean Protein Isolates/Concentrate: Effect of Raw Material Composition and Extrusion Parameters on Texture Properties. Foods 2021, 10, 843. [CrossRef]

10. Wittek, P.; Zeiler, N.; Karbstein, H.P.; Emin, M.A. High Moisture Extrusion of Soy Protein: Investigations on the Formation of Anisotropic Product Structure. Foods 2021, 10, 102. [CrossRef] [PubMed]

11. Pietsch, V.L.; Bühler, J.M.; Karbstein, H.P.; Emin, M.A. High moisture extrusion of soy protein concentrate: Influence of thermomechanical treatment on protein-protein interactions and rheological properties. J. Food Eng. 2019, 251, 11-18. [CrossRef]

12. Chen, F.L.; Wei, Y.M.; Zhang, B.; Ojokoh, A.O. System parameters and product properties response of soybean protein extruded at wide moisture range. J. Food Eng. 2010, 96, 208-213. [CrossRef]

13. Liu, K.S.; Hsieh, F.-H. Protein-Protein Interactions in High Moisture-Extruded Meat Analogs and Heat-Induced Soy Protein Gels. J. Am. Oil Chem. Soc. 2007, 84, 741-748. [CrossRef]

14. Liu, K.; Hsieh, F.-H. Protein-protein interactions during high-moisture extrusion for fibrous meat analogues and comparison of protein solubility methods using different solvent systems. J. Agric. Food Chem. 2008, 56, 2681-2687. [CrossRef]

15. Park, J.-H.; Chatpaisarn, A.; Ryu, G.-H. Effects of Gluten and Moisture Contents on Texturization of Extruded Soy Protein Isolate. J. Korean Soc. Food Sci. Nutr. 2017, 46, 473-480. [CrossRef]

16. Chiang, J.H.; Loveday, S.M.; Hardacre, A.K.; Parker, M.E. Effects of soy protein to wheat gluten ratio on the physicochemical properties of extruded meat analogues. Food Struct. 2019, 19, 100102. [CrossRef]

17. Zhang, J.; Liu, L.; Zhu, S.; Wang, Q. Texturisation behaviour of peanut-soy bean/wheat protein mixtures during high moisture extrusion cooking. Int. J. Food Sci. Nutr. 2018, 53, 2535-2541. [CrossRef]

18. Samard, S.; Gu, B.-Y.; Ryu, G.-H. Effects of extrusion types, screw speed and addition of wheat gluten on physicochemical characteristics and cooking stability of meat analogues. J. Sci. Food Agric. 2019, 99, 4922-4931. [CrossRef]

19. Wu, M.; Huang, X.; Gao, F.; Sun, Y.; Duan, H.; Li, D. Dynamic mechanical properties and fractal analysis of texturized soybean protein/wheat gluten composite produced by high moisture extrusion. Int. J. Food Sci. Nutr. 2019, 54, 499-508. [CrossRef] 
20. Zahari, I.; Ferawati, F.; Helstad, A.; Ahlström, C.; Östbring, K.; Rayner, M.; Purhagen, J.K. Development of High-Moisture Meat Analogues with Hemp and Soy Protein Using Extrusion Cooking. Foods 2020, 9, 772. [CrossRef]

21. Maung, T.-T.; Gu, B.-Y.; Ryu, G.-H. Influence of extrusion process parameters on specific mechanical energy and physical properties of high-moisture meat analog. Int. J. Food Eng. 2021, 17, 149-157. [CrossRef]

22. Thadavathi, Y.L.; Wassén, S.; Kádár, R. In-line rheological and microstroctural characterization of high moisture content protein vegetable mixtures in single screw extrusion. J. Food Eng. 2019, 245, 112-123. [CrossRef]

23. Grabowska, K.J.; Tekidou, S.; Boom, R.M.; van der Goot, A.-J. Shear structuring as a new method to make anisotropic structures from soy-gluten blends. Food Res. Int. 2014, 64, 743-751. [CrossRef] [PubMed]

24. Tolstoguzov, V.B. Thermoplastic extrusion-the mechanism of the formation of extrudate structure and properties. J. Am. Oil Chem. Soc. 1993, 70, 417-424. [CrossRef]

25. Tolstoguzov, V.B.; Grinberg, V.Y.; Gurov, A.N. Some physicochemical approaches to the problem of protein texturization. J. Agric. Food Chem. 1985, 33, 151-159. [CrossRef]

26. Tolstoguzov, V.B. Some physico-chemical aspects of protein processing into foodstuffs. Food Hydrocoll. 1988, 2, 339-370. [CrossRef]

27. Nishinari, K.; Fang, Y.; Guo, S.; Phillips, G.O. Soy proteins: A review on composition, aggregation and emulsification. Food Hydrocoll. 2014, 39, 301-318. [CrossRef]

28. Emin, M.A.; Schuchmann, H.P. Droplet breakup and coalescence in a twin-screw extrusion processing of starch based matrix. J. Food Eng. 2013, 116, 118-129. [CrossRef]

29. Berry, G.C.; Fox, T. The viscosity of polymers and their concentrated solutions. In Fortschritte der Hochpolymeren-Forschung; Springer: Berlin/Heidelberg, Germany, 1968; pp. 261-357, ISBN 3-540-04032-3.

30. Dekkers, B.L.; Emin, M.A.; Boom, R.M.; van der Goot, A.J. The phase properties of soy protein and wheat gluten in a blend for fibrous structure formation. Food Hydrocoll. 2018, 79, 273-281. [CrossRef]

31. Fang, Y.; Zhang, B.; Wei, Y. Effects of the specific mechanical energy on the physicochemical properties of texturized soy protein during high-moisture extrusion cooking. J. Food Eng. 2014, 121, 32-38. [CrossRef]

32. Gorissen, S.H.M.; Crombag, J.J.R.; Senden, J.M.G.; Waterval, W.A.H.; Bierau, J.; Verdijk, L.B.; van Loon, L.J.C. Protein content and amino acid composition of commercially available plant-based protein isolates. Amino Acids 2018, 50, 1685-1695. [CrossRef]

33. Reidy, P.T.; Walker, D.K.; Dickinson, J.M.; Gundermann, D.M.; Drummond, M.J.; Timmerman, K.L.; Fry, C.S.; Borack, M.S.; Cope, M.B.; Mukherjea, R.; et al. Protein blend ingestion following resistance exercise promotes human muscle protein synthesis. J. Nutr. 2013, 143, 410-416. [CrossRef]

34. Paul, G.L. The rationale for consuming protein blends in sports nutrition. J. Am. Coll. Nutr. 2009, 28, 464S-472S. [CrossRef] [PubMed]

35. Yada, R.Y. Proteins in Food Processing; CRC Press: Boca Raton, FL, USA; Cambridge, UK, 2004, ISBN 185573723x.

36. Hertzler, S.R.; Lieblein-Boff, J.C.; Weiler, M.; Allgeier, C. Plant Proteins: Assessing Their Nutritional Quality and Effects on Health and Physical Function. Nutrients 2020, 12, 3704. [CrossRef]

37. Russell, T.A.; Drake, M.A.; Gerard, P.D. Sensory Properties of Whey and Soy Proteins. J. Food Sci. 2006, 71, S447-S455. [CrossRef]

38. Sandoval-Castilla, O.; Lobato-Calleros, C.; Aguirre-Mandujano, E.; Vernon-Carter, E.J. Microstructure and texture of yogurt as influenced by fat replacers. Int. Dairy J. 2004, 14, 151-159. [CrossRef]

39. Osen, R.; Toelstede, S.; Wild, F.; Eisner, P.; Schweiggert-Weisz, U. High moisture extrusion cooking of pea protein isolates: Raw material characteristics, extruder responses, and texture properties. J. Food Eng. 2014, 127, 67-74. [CrossRef]

40. Emin, M.A.; Quevedo, M.; Wilhelm, M.; Karbstein, H.P. Analysis of the reaction behavior of highly concentrated plant proteins in extrusion-like conditions. Innov. Food Sci. Emerg. Technol. 2017, 44, 15-20. [CrossRef]

41. Wittek, P.; Zeiler, N.; Karbstein, H.P.; Emin, M.A. Analysis of the complex rheological properties of highly concentrated proteins with a closed cavity rheometer. Appl. Rheol. 2020, 30, 64-76. [CrossRef]

42. Emin, M.A.; Schuchmann, H.P. A mechanistic approach to analyze extrusion processing of biopolymers by numerical, rheological, and optical methods. Trends Food Sci. Tech. 2017, 60, 88-95. [CrossRef]

43. Steffe, J.F. Rheological Methods in Food Process Engineering, 2nd ed.; Freeman Press: East Lansing, MI, USA, 1996, ISBN 9780963203618.

44. Shih, C.K. Rheological properties of incompatible blends of two elastomers. Polym. Eng. Sci. 1976, 16, 742-746. [CrossRef]

45. Wang, J.; Porter, R.S. On the viscosity-temperature behavior of polymer melts. Rheol. Acta 1995, 34, 496-503. [CrossRef]

46. Quevedo, M.; Kulozik, U.; Karbstein, H.P.; Emin, M.A. Influence of Thermomechanical Treatment and Ratio of $\beta$-Lactoglobulin and $\alpha$-Lactalbumin on the Denaturation and Aggregation of Highly Concentrated Whey Protein Systems. Foods 2020, 9, 1196. [CrossRef] [PubMed]

47. Quevedo, M.; Kulozik, U.; Karbstein, H.P.; Emin, M.A. Effect of thermomechanical treatment on the aggregation behaviour and colloidal functionality of $\beta$-Lactoglobulin at high concentrations. Int. Dairy J. 2020, 104, 104654. [CrossRef]

48. Quevedo, M.; Karbstein, H.P.; Emin, M.A. Denaturation Behavior and Kinetics of Single- and Multi-Component Protein Systems at Extrusion-Like Conditions. Polymers 2020, 12, 2145. [CrossRef] [PubMed]

49. Ranasinghesagara, J.; Hsieh, F.-H.; Yao, G. An Image Processing Method for Quantifying Fiber Formation in Meat Analogs Under High Moisture Extrusion. J. Food Sci. 2005, 70, e450-e454. [CrossRef]

50. Palanisamy, M.; Töpfl, S.; Aganovic, K.; Berger, R.G. Influence of iota carrageenan addition on the properties of soya protein meat analogues. LWT 2018, 87, 546-552. [CrossRef]

51. Schreuders, F.; Sagis, L.; Bodnár, I.; Erni, P.; Boom, R.M.; van der Goot, A.J. Small and large oscillatory shear properties of concentrated proteins. Food Hydrocoll. 2021, 110, 106172. [CrossRef] 
52. Wittek, P.; Walther, G.; Karbstein, H.P.; Emin, M.A. Comparison of the rheological properties of plant proteins from various sources for extrusion applications. Foods 2021, in press.

53. Hyun, K.; Wilhelm, M.; Klein, C.O.; Cho, K.S.; Nam, J.G.; Ahn, K.H.; Lee, S.J.; Ewoldt, R.H.; McKinley, G.H. A review of nonlinear oscillatory shear tests: Analysis and application of large amplitude oscillatory shear (LAOS). Prog. Polym. Sci. 2011, 36, 1697-1753. [CrossRef]

54. Utracki, L.A.; Wilkie, C.A. (Eds.) Polymer Blends Handbook; Springer: Dordrecht, The Netherlands, 2014, ISBN 978-94-007-6063-9.

55. Kanu, R.C.; Shaw, M.T. Rheology of polymer blends: Simultaneous slippage and entrance pressure loss in the ethylene-propylenediene (EPDM)/viton system. Polym. Eng. Sci. 1982, 22, 507-511. [CrossRef]

56. Utracki, L.A.; Kanial, M.R. Melt rheology of polymer blends. Polym. Eng. Sci. 1982, 22, 96-114. [CrossRef]

57. Emin, M.A.; Schuchmann, H.P. Analysis of the dispersive mixing efficiency in a twin-screw extrusion processing of starch based matrix. J. Food Eng. 2013, 115, 132-143. [CrossRef]

58. Emin, M.A.; Wittek, P.; Schwegler, Y. Numerical analysis of thermal and mechanical stress profile during the extrusion processing of plasticized starch by non-isothermal flow simulation. J. Food Eng. 2021, 294, 110407. [CrossRef]

59. Cornet, S.H.V.; Snel, S.J.E.; Schreuders, F.K.G.; van der Sman, R.G.M.; Beyrer, M.; van der Goot, A.J. Thermo-mechanical processing of plant proteins using shear cell and high-moisture extrusion cooking. Crit. Rev. Food Sci. Nutr. 2021, 1-18. [CrossRef]

60. Son, Y. Determination of shear viscosity and shear rate from pressure drop and flow rate relationship in a rectangular channel. Polymer 2007, 48, 632-637. [CrossRef]

61. Wittek, P.; Ellwanger, F.; Karbstein, H.P.; Emin, M.A. Morphology development and flow characteristics during high moisture extrusion of a plant-based meat analogue. Foods 2021, in press.

62. Hanafy, G.M.; Madbouly, S.A.; Ougizawa, T.; Inoue, T. Effects of AN-contents and shear flow on the miscibility of PC/SAN blends. Polymer 2004, 45, 6879-6887. [CrossRef]

63. Dekkers, B.L.; Hamoen, R.; Boom, R.M.; van der Goot, A.J. Understanding fiber formation in a concentrated soy protein isolate-Pectin blend. J. Food Eng. 2018, 222, 84-92. [CrossRef]

64. Filipe, S.; Cidade, M.T.; Wilhelm, M.; Maia, J.M. Evolution of morphological and rheological properties along the extruder length for blends of a commercial liquid crystalline polymer and polypropylene. Polymer 2004, 45, 2367-2380. [CrossRef] 